TINDAK TUTUR DIREKTIF DALAM FILM

\title{
AKU INGIN IBU PULANG KARYA MONTY TIWA SEBAGAI ALTERNATIF BAHAN AJAR TEKS DRAMA KELAS XI SMa
}

\author{
NUR KHASANAH',EVI CHAMALAH ${ }^{2}$, MEILAN ARSANTI ${ }^{3}$ \\ Universitas Islam Sultan Agung \\ khasanahnur@std.unissula.ac.id', chamalah@unissula.ac.id², meilanarsanti@unissula.ac.id³ \\ Pertama Diterima: 12 Oktober 2020 \\ Bukti Akhir Diterima: I5 Desember 2020
}

\begin{abstract}
Abstrak
Bahasa mempunyai peran vital dalam kehidupan manusia. Komunikasi yang dilakukan manusia dilakukan dengan menggunakan bahasa. Film merupakan jenis komunikasi secara tertulis. Dalam film terjadi bentuk komunikasi dan interaksi yang dilakukan tokoh melalui tuturan. Penelitian ini bertujuan untuk mendeskripsikan bentuk dan fungsi tindak tutur direktif dalam film Aku Ingin Ibu Pulang karya Monty Tiwa serta mendeskripsikan implementasi tindak tutur direktif yang terdapat dalam film Aku Ingin Ibu Pulang karya Monty Tiwa sebagai alternatif bahan ajar teks drama kelas XI SMA. Metode yang digunakan pada penelitian ini adalah metode kualitatif. Teknik pengumpulan data ini adalah simak dan catat. Instrumen penelitian ini adalah peneliti sendiri (human instrument) dibantu dengan alat bantu berupa kartu data. Sedangkan teknik analisis data penelitian ini meliputi, (1) pengumpulan data, (2) reduksi data, (3) penyajian data, dan (4) penarikan kesimpulan. Hasil penelitian ini menunjukkan bahwa, 1) tindak tutur direktif tidak dapat dipisahkan dari kelangsungan hidup manusia dan 2) tindak tutur direktif dalam film Aku Ingin Ibu Pulang karya Monty Tiwa dapat diimplementasikan sebagai alternatif bahan ajar pada pembelajaran teks drama kelas XI SMA.
\end{abstract}

Kata kunci: direktif, fungsi, pembelajaran, teks drama

\begin{abstract}
Language has a vital role in human life. Communication by humans is done using language. Movie is a type of written communication. In the movie there is a communication and interaction between the characters through speech. This research is to describe the form and function of directive speech act in the movie Aku Ingin Ibu Pulang by Monty Tiwa and also describing the implementation of directive speech act contained in this movie as alternative teaching material drama text for 11th grade students of senior high school. This research used qualitative method. The data collection technique is simak and baca technique. The instrument of this reseach is the researcher himself (human instrument) assisted by data cards. While the data analysis techniques of this research include, (1) data collection, (2) data reduction, (3) data presentation, and (4) conclusions. The results of this study indicate that, 1) directive speech acts cannot be separated from human survival and 2) directive speech acts in the film Aku Ingin Ibu Pulang by Monty Tiwa can be implemented as an alternative teaching material in learning drama text for class XI SMA.
\end{abstract}

Keywords: directive, function, learning, drama text

\section{PENDAHULUAN}

Bahasa merupakan alat komunikasi manusia. Bahasa dalam kehidupan manusia bersifat penting mengingat manusia senantiasa berinteraksi antarsesama. Interaksi manusia sendiri merupakan upaya untuk menyampaikan suatu pesan, ide, persoalan hidup atau pandangan tentang suatu kehidupan manusia itu sendiri. Chaer (2010: 15) menyatakan bahwa penutur dalam suatu tuturan menggunakan sebuah bahasa untuk melakukan komunikasi dan berinteraksi. Komunikasi 
tidak hanya sekadar lisan, tetapi juga dapat melalui tulisan. Seperti halnya komunikasi manusia sehari-hari, dalam sebuah film termuat serangkaian proses berbahasa antartokoh melaui dialog yang dibuat oleh pengarang. Dialog-dialog pada film, terkadang membuat pembaca dapat merasakan dan mengetahui apa yang dirasakan oleh tokoh tersebut.

Tindak tutur direktif merupakan gejala berbahasa yang seringkali dialami manusia pada saat berkomunikasi. Dalam kegiatan komunikasi, manusia menggunakan bahasa sebagai media penyampaian pesan dan maksud tertentu. Kegiatan yang dilakukan manusia tersebut erat kaitannya dengan tindakan-tindakan di setiap tuturan (Yule 2014: 82). Menurut Prayitno (2011: 46-84), tindak tutur direktif terbagi menjadi enam bentuk, yaitu perintah, permintaan, ajakan, nasihat, kritikan, dan larangan. Seperti disebutkan di atas, komunikasi secara tertulis salah satunya melalui media film. Film merupakan karya jurnalistik yang mencerminkan kehidupan manusia dalam bentuk video dengan maksud dipertunjukkan oleh aktor. Dalam film berisikan kejadian atau peristiwa yang dialami seseorang, baik itu kejadian yang baik maupun buruk. Pada film juga diperlihatkan watak manusia dalam kehidupan sehari-hari. Hal paling menonjol dalam film adalah adanya interaksi antartokoh satu dengan tokoh lainnya melalui tuturan. Pada film, dialog yang diucapkan para aktor berdasarkan adaptasi naskah novel atau cerita pendek yang kemudian dijadikan sebuah film. Penulis naskah berperan sebagai pengarang pada tulisannya sendiri untuk memberikan pesan atau informasi dengan mengunakan berbagai tindak tutur. Pesan atau informasi tersebut dituliskan oleh pengarang menjadi sebuah dialog yang kemudian akan diperagakan aktor.

Sesuai Kurikulum 2013 revisi 2018, silabus SMA mata pelajaran Bahasa Indonesia kelas XI, memuat salah satu Kompetensi Dasar (KD) yang erat kaitannya dengan komunikasi, yaitu KD 4.19 mendemonstrasikan sebuah naskah drama dengan memperhatikan isi dan kebahasaan. Pada KD tersebut, siswa diharapkan mampu menyusun kembali teks drama dengan memperhatikan unsurunsur pembangun drama. Adapun drama tidak terlepas dari adanya proses berbahasa, yaitu adanya dialog-dialog berupa tuturan antartokoh yang terdapat dalam sebuah drama. Dalam drama, dialog antara tokoh satu dengan tokoh lainnya merupakan hal yang tidak dapat dipisahkan.

Pada proses pembelajaran bahasa Indonesia di sekolah, masih ditemukannya ketidakefektifan dan ketidakpahaman siswa dalam membuat teks drama yang berhubungan dengan unsur tindak tutur direktif. Padahal unsur tindak tutur direktif merupakan aspek yang vital dalam penciptaan suatu teks cerita, baik itu dalam wujud teks drama maupun teks cerpen. Selain dialog maupun cerita menjadi menjadi tidak menarik, kaku, dan monoton, penggunaan tindak tutur direktif yang tidak tepat membuat alur cerita menjadi membosankan. Oleh sebab itu, diperlukan penelitian lebih lanjut mengenai bentuk dan fungsi tindak tutur direktif untuk melengkapi, bahkan menyempurnakan kekurangan tersebut agar siswa mampu memproduksi suatu teks drama.

\section{METODE}

Metode penelitian yang digunakan adalah metode kualitatif. Penelitian kualitatif merupakan serangkaian metode penelitian yang hasil penelitiannya dalam bentuk data deskriptif berupa katakata tertulis atau lisan dari orang-orang dan perilaku yang diamati Muhammad (dalam Moleong 2010: 4). Penelitian kualitatif akan menghasilkan data-data berbentuk deskripsi sesuai dengan fenomena-fenomena kebahasaan yang terdapat di sekitar manusia. 
Sudaryanto (1988: 9) menyatakan bahwa data adalah bahan penelitian. Data penelitian ini adalah data lisan yang mengandung tindak tutur direktif yang meliputi bentuk dan fungsi tindak tutur direktif yang terdapat dalam dialog film Aku Ingin Ibu Pulang karya Monty Tiwa. Adapun sumber data yang digunakan pada penelitian ini adalah film Aku Ingin Ibu Pulang karya Monty Tiwa.

Teknik pengumpulan data dalam penelitian ini adalah teknik simak dan catat. Mahsun (2005: 92) menyatakan bahwa teknik simak adalah sebuah metode penyajian data yang bertujuan untuk memperoleh data dengan cara menyimak penggunaan bahasa. Pada teknik ini, peneliti hanya sebagai pengamat dan tidak terlibat dalam peristiwa tutur. Peneliti diharuskan mencatat beberapa bentuk yang relevan dari penggunaan bahasa secara tertulis dalam penelitian yang dilakukan (Mahsun 2005: 93). Teknik catat dalam penelitian ini digunakan untuk mencatat hasil menyimak dialog film Aku Ingin Ibu Pulang karya Monty Tiwa.

Arikunto (2010: 265) menyatakan bahwa semua alat yang digunakan untuk mengumpulkan, menyelidiki masalah, memeriksa, mengolah, menganalisa dan menyajikan data yang digunakan dalam penelitian merupakan instrumen pengumpulan data. Instrumen penelitian ini adalah peneliti sendiri (human instrument) dibantu dengan alat bantu berupa kartu data yang digunakan untuk menuliskan data hasil dari menyimak dialog dalam film Aku Ingin Ibu Pulang karya Monty Tiwa.

Menurut Sugiyono (2014: 92) teknik analisis data dalam sebuah penelitian terbagi menjadi empat langkah. Adapun dalam penelitian ini, teknik analisis data penelitian didasarkan pada pendapat Sugiyono (2014: 92) yang meliputi, (1) pengumpulan data, (2) reduksi data, (3) penyajian data, dan (4) penarikan kesimpulan.

\section{HASIL PENELITIAN DAN PEMBAHASAN}

Berdasarkan hasil penelitian terdapat 85 data tuturan yang diteliti, film Aku Ingin Ibu Pulang karya Monty Tiwa berupa bentuk tuturan direktif, yaitu perintah, permintaan, ajakan, nasihat, kritikan, dan larangan. Tindak tutur direktif perintah berjumlah 16 data tuturan, permintaan berjumlah 31 data tuturan, ajakan berjumlah 5 data tuturan, nasihat berjumlah 16 data tuturan, kritikan berjumlah 10 data tuturan, dan larangan berjumlah 7 data tuturan. Berikut akan dibahas keenam bentuk tindak tutur yang ditemukan dalam film Aku Ingin Ibu Pulang karya Monty Tiwa.

\section{Bentuk Tindak Tutur Direktif dalam Film Aku Ingin Ibu Pulang karya Monty Tiwa}

a. Bentuk Perintah

Tuturan (1)

Ibu Guru : Ehh Jempol. Siapa yang nyuruh kamu masuk? Terlambat lagi hari ini, tunggu di luar!

Jempol : Uhh... (merasa bersalah)

Tuturan (1) dituturkan oleh Ibu guru dan Jempol. Pada tuturan tersebut, Ibu Guru bermaksud memerintah Jempol untuk menunggu di luar kelas. Adapun menunggu di luar yang dimaksud adalah Ibu Guru tidak mengizinkan Jempol untuk mengikuti pembelajaran di kelas karena Jempol datang terlambat. Tuturan tunggu di luar!merupakan bentuk penegasan 
dari sebuah perintah yang bersifat lugas dan padat (seperti aba-aba komando dalam kegiatan militer) yang harus dikerjakan atau dilakukan saat itu juga.

b. Bentuk Permintaan

Tuturan (2)

Satri : Dok, ini kira-kira abis berapa, ya?

Dokter : Ini ada empat jenis, nah per jenis itu kurang lebih paling mahal itu lima puluh ribu.

Tuturan (2) dituturkan oleh Satri dan dokter. Tuturan Satri yang tertulis, Dok, ini kira-kira abis berapa, ya?, termasuk tindak tutur direktif permintaan. Adapun maksud dari tuturan tersebut adalah Satri meminta informasi kepada dokter tentang harga obat. Indikator tuturan Dok, ini kira-kira abis berapa, ya? sebagai tindak tutur direktif permintaan ditandai dengan pengaruh yang ditimbulkan kepada mitra tutur untuk melakukan sesuatu. Pengaruh tersebut menyebabkan dokter memberikan informasi yang diinginkan oleh Satri. Pengaruh kepada mitra tuturnya dapat diketahui melalui tuturan dokter yang tertulis, Ini ada empat jenis, nah per jenis itu kurang lebih paling mahal itu lima puluh ribu.

c. Bentuk Ajakan

Tuturan (3)

Tiwi : Udah yuk ah, pulang.

Jempol : Yuk.

Tuturan (3) dituturkan oleh Tiwi dan Jempol. Indikator yang menyatakan tuturan Tiwi sebagai tindak tutur direktif ajakan ditandai dengan adanya kata yuk (ayo) pada tuturan Tiwi. Kata yuk berfungsi mempertegas maksud ajakan agar mitra tutur bersedia melakukan sesuatu sebagaimana yang dituturkan oleh penutur. Adapun maksud ajakan dalam tuturan Tiwi di atas adalah Tiwi mengajak Jempol untuk pulang ke rumah.

d. Bentuk Nasihat

Tuturan (4)

Ibu Guru : Eitss.. satu lagi. Kalau ke sekolah jangan datang terlambat dong ya Jempol. Jempol : Iya bu.

Tuturan (4) dituturkan Ibu guru oleh dan Jempol. Indikator tuturan Ibu guru disebut sebagai tindak tutur direktif nasihat ditandai dengan efek yang ditimbulkan kepada mitra tutur untuk berbuat sesuatu seperti yang diinginkan penutur. Efek tersebut terlihat dari tuturan Jempol yang tertulis, Iya bu. Dari tuturan Jempol tersebut, mengindikasikan bahwa Jempol bersedia melakukan sesuatu seperti yang diinginkan Ibu guru, yaitu tidak akan datang terlambat ke sekolah. Dalam tuturan Ibu guru di atas, Ibu Guru menasihati Jempol agar tidak terbiasa untuk datang terlambat ke sekolah. 
e. Bentuk Kritikan

Tuturan (5)

Ibu Tiwi : Tiwi, Jempol, nih anak berdua udah dikasih tahu kalau pulang sekolah gak boleh main dulu.

Jempol\&Tiwi : Iya Bu.

Tuturan (5) dituturkan oleh ibu Tiwi dan Jempol dan Tiwi. Indikator tuturan Ibu Tiwi ditandai dengan adanya teguran atau masukan secara keras atas tindakan yang dilakukan oleh mitra tutur. Dari tuturan di atas, dapat dipahami jika ibu Tiwi menegur Jempol dan Tiwi untuk tidak bermain setelah pulang sekolah. Kritikan dalam bentuk teguran tersebut diberikan dengan tujuan agar mereka lebih menghargai waktu untuk beristirahat di rumah dan memungkinkan melakukan kegiatan seperti belajar daripada harus membuang waktu demi bermain.

f. Bentuk Larangan

Tuturan (6)

Satri : Jangan dipikiran ya. Sehat aja ya dulu.

Bagus : Makasih bu.

Tuturan (6) dituturkan oleh Satri dan Bagus. Indikator tuturan Satri sebagai tindak tutur direktif larangan ditandai dengan adanya kata jangan pada tuturan Satri. Kata jangan merupakan kata yang biasanya digunakan untuk melarang seseorang berbuat atau melakukan sesuatu. Kata jangan dalam tuturan Satri di atas mempertegas maksud Satri agar Bagus tidak melakukan sesuatu di luar keinginan Satri. Dalam tuturannya, Satri melarang Bagus untuk tidak memikirkan hal lain selain kesehatannya.

\section{Fungsi Tindak Tutur Direktif dalam Film Aku Ingin Ibu Pulang karya Monty Tiwa}

Pada penelitian yang telah dilakukan, fungsi tindak tutur direktif yang ditemukan dalam film Aku Ingin Ibu Pulang karya Monty Tiwa sejumlah 24 data tuturan. Berikut akan dibahas fungsi tindak tutur yang ditemukan dalam film Aku Ingin Ibu Pulang karya Monty Tiwa.

a. Fungsi Menyuruh

Tuturan (1)

Tukang Bubur: Malah ketawa, catet! Entar lupa lagi lu.

Jempol : Sama aja bang, saya jago hapal.

Tuturan (1) dituturkan oleh Tukang Bubur dan Jempol. Indikator tuturan Tukang Bubur disebut sebagai tindak tutur direktif perintah dengan fungsi menyuruh ditandai dengan kata catet. Kata catet merupakan bentuk tuturan perintah. Kata catet bermakna suatu perintah agar seseorang melakukan sesuatu, yaitu mencatat. Adapun bentuk perintah yang diberikan Tukang Bubur adalah menyuruh kepada Jempol untuk segera mencatat nomor telepon yang sudah disebutkan oleh Tukang Bubur. 
b. Fungsi Memerintah

Tuturan (2)

Satri : Kamu juga tunggu sana di luar!

Jempol : Iya Bu.

Tuturan (2) dituturkan oleh Satri dan Jempol. Indikator tuturan Satri di atas ditandai dengan bentuk tuturan perintah yang simpel. Tuturan tunggu sana di luar! menegaskan sebuah perintah secara lugas dan padat. Adapun dalam tuturan Satri di atas, Satri memerintah Jempol untuk keluar dari kamar ayahnya yang sedang diobati oleh tukang pijit. Hal tersebut dilakukan karena Jempol mengganggu proses pengobatan yang sedang dijalani oleh ayahnya.

c. Fungsi Mengharuskan

Tuturan (3)

Ibu Tiwi : Pol, buruan lu, Bapak lu kan kecelakaan.

Jempol : Hah?

Tuturan (3) dituturkan oleh Ibu Tiwi dan Jempol. Indikator tuturan Ibu Tiwi ditandai dengan kata buruan. Kata buruan bermakna segera untuk melakukan sesuatu. Jika dicermati secara saksama, buruan yang dimaksud oleh Ibu Tiwi adalah mengharuskan kepada Jempol untuk sesegera mungkin menemui ayahnya yang mengalami kecelakaan.

d. Fungsi Memaksa

Tuturan (4)

Bagus : Minggat kamu! Aku bilang minggat kamu! Aku bilang minggat kamu! Minggat kamu! Minggat kamu! Minggat! Ya Allah.

Satri : Baik mas, kalau itu yang mas minta.

Tuturan (4) dituturkan oleh Bagus dan Satri. Indikator tuturan Bagus di atas ditandai dengan adanya pemaksaan melalui kata minggat. Kata minggat pada umumnya merupakan padanan kata yang berkonotasi negatif dan terkesan kasar. Kata minggat digunakan untuk menyatakan kepergian seseorang secara paksa dan harus saat itu juga (mengusir). Dari tuturan Bagus di atas, Bagus bermaksud mengusir Satri secara paksa dari rumahnya.

e. Fungsi Menyilakan

Tuturan (5)

Jempol : Makan Pak, nih bubur.

Bagus : Makasih ya Pol.

Tuturan (5) dituturkan oleh Jempol dan Bagus. Indikator tuturan Jempol ditandai dari maksud atau isi tuturannya, yaitu mempersilakan agar mitra tutur melakukan sebagaimana yang telah dituturkan penutur. Adapun maksud tersebut adalah Jempol mempersilakan agar 
Bagus memakan terlebih dulu daripada Jempol. Hal tersebut dilakukan untuk menghormati yang lebih tua.

\section{f. Fungsi Meminta}

Tuturan (6)

Bagus : : Tapi, uang kita ada berapa, bu?

Satri : Uang kita ada dua ratus ribu.Yang lima puluh buat tukang urut.

Tuturan (6) dituturkan oleh Bagus dan Satri. Indikator tuturan Bagus ditandai dengan keberhasilan Bagus memperoleh informasi yang diinginkan. Pada percakapan di atas, Bagus berhasil memperoleh informasi bahwa uang tersisa tinggal dua ratus ribu. Jika dicermati, Bagus tidak hanya memperoleh informasi itu saja, melainkan Satri juga menjelaskan rincian pemakaian uang kepada Bagus. Hal tersebut diketahui dari tuturan Satri yang tertulis, Yang lima puluh buat tukang urut.

g. Fungsi Mengharap

Tuturan (7)

Panitia Lomba: Kalau yang itu?

Jempol : Pencarian ibu saya.

Panitia Lomba: Mudah-mudahan cepet ketemu ya Jempol.

Jempol : Iya.

Tuturan (7) dituturkan oleh Panitia lomba dan Jempol. Tuturan panitia lomba yang tertulis, Mudah-mudahan cepet ketemu ya Jempol, merupakan bentuk tindak tutur direktif permintaan dengan fungsi mengharap. Indikator tuturan panitia lomba ditandai dengan adanya maksud mengharap. Adapun mengharap yang dimaksud adalah panitia lomba berharap Jempol dapat menemukan ibunya yang pergi dari rumah.

h. Fungsi Memohon

Tuturan (8)

Satri : Suami saya abis jatuh koh, enggak bisa kerja.

Koh Herman : Yaudah, perkara minta obat lu ambil aja sendiri noh. Asal jangan minta duit aja lu.

Tuturan (8) dituturkan oleh Satri dan Koh Herman. Pada tuturan di atas, tuturan Satri yang tertulis, Suami saya abis jatuh koh, enggak bisa kerja, termasuk ke dalam tindak tutur permintaan dengan fungsi memohon. Tuturan Satri merupakan bentuk permohonan Satri agar Koh Herman memenuhi dan melakukan apa yang diinginkan Satri. Permohonan yang diajukan Satri kepada Koh Herman berupa meminta kepada Koh Herman agar Koh Herman bersedia memberikan obat untuk pengobatan suami Satri yang sedang sakit. 
i. Fungsi Menawarkan

Tuturan (9)

Koh Herman : Ya lu pilih dah, lu mau jagain suami atau mau kerja. Kalau mau jagain suami, besok gua cari pengganti.

Satri : Jangan koh, jangan. Janji gak akan telat lagi. Enggak, enggak bakal.

Tuturan (9) dituturkan oleh Koh Herman dan Satri. Pada percakapan di atas, tuturan Koh Herman yang tertulis, Ya lu pilih dah, lu mau jagain suami atau mau kerja, termasuk ke dalam tindak tutur direktif permintaan dengan fungsi menawarkan. Indikator tuturan Koh Herman ditandai dengan adanya penawaran kepada Satri dalam tuturan Koh Herman. Penawaran tersebut adalah Koh Herman memberikan pilihan kepada Satri untuk mempertimbangkan sekaligus menentukan pilihan antara menjaga suami yang sedang sakit atau kerja.

j. Fungsi Mengajak

Tuturan (10)

Jempol : Wi, nanti kalau bapakku sembuh, kamu ikut kita jalan-jalan ya?

Tiwi : Benar ya pol.

Jempol : Benar, janji.

Tuturan (10) dituturkan oleh Jempol dan Tiwi. Indikator tuturan ajakan Jempol ditandai dengan adanya efek yang ditimbulkan kepada mitra tutur. Efek tersebut dapat dilihat dari tuturan Tiwi yang tertulis, Benar ya pol. Tuturan tersebut mengindikasikan bahwa Tiwi bersedia melakukan sesuatu seperti yang diminta Jempol, yaitu ikut jalan-jalan bersama keluarga Jempol. Dari tuturan Tiwi di atas, juga dapat dipahami jika Tiwi sangat antusias menyambut ajakan Jempol untuk ikut jalan-jalan bersama keluarga Jempol.

k. Fungsi Mendorong

Tuturan (11)

Tiwi : Udah yuk ah, pulang.

Jempol : Yuk.

Tuturan (11) dituturkan oleh Tiwi dan Jempol. Tuturan Tiwi yang tertulis, Udah yuk ah, pulang,termasuk tindak tutur direktif ajakan dengan fungsi mendorong. Indikator tuturan Tiwi ditandai adanya kata yuk (ayo) pada tuturan Tiwi. Kata yuk berfungsi untuk menyatakan suatu ajakan kepada mitra tutur. Adapun maksud ajakan dalam tuturan Tiwi di atas adalah Tiwi mengajak Jempol untuk pulang ke rumah sesegera mungkin mengingat sebentar lagi azan magrib berkumandang.

1. Fungsi Mendesak

Tuturan (12)

Jempol : Ayok dok.

Dokter : Iya iya sebentar-sebentar. 
Tuturan (12) dituturkan oleh Jempol dan dokter. Konteks percakapan keduanya mengenai Jempol menyuruh dokter untuk mempercepat laju kendaraan motornya mengingat ayah Jempol sedang sakit. Indikator tuturan Jempol ditandai dengan adanya kata Ayok. Kata Ayok berfungsi untuk menyatakan ajakan kepada mitra tutur agar bersedia melalukan sesuatu seperti yang diminta penutur. Dalam tuturan Jempol di atas, Jempol mendesak dokter untuk mempercepat laju kendaraan motornya mengingat keadaan ayah Jempol yang harus segera memperoleh pertolongan medis.

m. Fungsi Merayu

Tuturan (13)

Satri : Mas, kok kayaknya kakinya enggak membaik ya mas. Urut lagi ya? Satri panggil ya tukang urut ya?

Bagus : Huuuusss.. aja Tri. Kita mesti ngirit. Ini masih awal bulan. Duit tinggal sedikit, kamu harus percaya aku akan sembuh, ya.

Tuturan (13) dituturkan oleh Satri dan Bagus. Tuturan Satri yang tertulis, Mas, kok kayaknya kakinya enggak membaik ya mas. Urut lagi ya?, termasuk ke dalam tindak tutur direktif ajakan dengan fungsi merayu. Indikator tuturan Satri di atas ditandai dengan adanya representasi Satri membujuk atau mendorong dengan iba agar Bagus bersedia melakukan sesuatu seperti yang diminta Satri. Bujukan yang dilakukan Satri didasari oleh kaki Bagus yang tidak kunjung sembuh. Dalam tuturannya, Satri membujuk Bagus agar bersedia dipijat lagi oleh tukang pijat.

n. Fungsi Menasihati

Tuturan (14)

Bagus : Ya kalau kamu punya cita-cita, ya harus digantung di Monas. Artine, harapan itu harus besar, cita-cita harus tinggi. Gitu lho.

Jempol : Hmm...

Tuturan (14) dituturkan oleh Bagus dan Jempol. Indikator yang menunjukkan tuturan Bagus termasuk tindak tutur direktif nasihat dengan fungsi menasihati ditandai dari isi tuturan Bagus. Pada tuturan Bagus, terdapat sebuah nasihat yang berisi pelajaran terpetik, baik itu petunjuk, ajaran, anjuran, atau teguran yang sifatnya mengandung kebaikan. Isi nasihat dari Bagus tersebut adalah agar Jempol senantiasa memiliki semangat dalam mencapai cita-cita yang diinginkannya.

o. Fungsi Menganjurkan

Tuturan (15)

Dokter : Ini diminum sesuai aturan pakai, ya, mbak.

Satri : Iya, dok.

Tuturan (15) dituturkan oleh dokter dan Satri. Indikator tuturan dokter ditandai dengan adanya anjuran. Dalam tuturannya, dokter menganjurkan kepada Satri agar Satri menggunakan obat sesuai aturan yang tertera dalam resep dokter. Dokter menganjurkan 
demikian agar tidak ada kejadian yang tidak diinginkan, seperti pasien overdosis obat.

p. Fungsi Menyarankan

Tuturan (16)

Satri : Nanti kan mas sembuh, mas bisa kerja lagi, mas balikin uang Jempol.

Bagus $\quad$ : Aku gak bisa, nanti duitnya cepat abis.

Tuturan (16) dituturkan oleh Satri dan Bagus. Tuturan Satri yang tertulis, Nanti kan mas sembuh, mas bisa kerja lagi, mas balikin uang Jempol, termasuk sebagai tindak tutur direktif nasihat dengan fungsi menyarankan. Indikator tuturan Satri ditandai dari isi tuturannya. Dalam tuturannya, Satri bermaksud menyarankan kepada Bagus untuk mementingkan kesehatan tubuhnya dibandingkan memikirkan kerja. Hal tersebut dilakukan oleh Satri agar Bagus lekas sembuh.

q. Fungsi Mengarahkan

Tuturan (17)

Satri : Perhatiin ya pol. Yang ini tempat bapakmu pipis dan eek. Ya? Nanti kalau udah selesai cebokin. Jangan lupa dilapin dulu ya, kasihan pantatnya gatel, ya?

Jempol : Iya bu.

Tuturan (17) dituturkan oleh Satri dan Jempol. Indikator tuturan Satri ditandai dengan adanya sebuah nasihat dalam bentuk arahan. Dalam tuturannya, Satri memberi arahan kepada Jempol untuk membantu Satri mengurus ayahnya yang sedang sakit. Arahan tersebut meliputi, 1) memperlihatkan tempat buang air kecil dan besar, 2) membersihkan kotoran ayah, dan 3) mengeringkan tubuh ayah dengan kain. Arahan tersebut diberikan Satri kepada Jempol untuk memudahkan Jempol mengurus ayahnya yang sakit.

r. Fungsi Menyerukan

Tuturan (18)

Koh Herman : Trus maksud lu apa?

Satri : Gaji bulan ini ambil dari bulan depan, koh.

Koh Herman : Wah gila bener lu ye Tri. Mana ada sejarahnya pegawai yang udah ngutang banyak ngambil gaji bulan depan, padahal masuknya telat mulu. Lu pikir gua sinterklas apa? Eh Tri, gua gak pecat aja udah bagus! Contoh nih ye semua! Enggak ada yang kek gini.

Tuturan (18) dituturkan oleh Koh Herman dan Satri. Indikator tuturan Koh Herman ditandai dengan adanya anjuran atau peringatan secara tegas dan sungguh-sungguh kepada Satri agar Satri melakukan sesuatu seperti yang diminta penutur. Adapun maksud tuturan Koh Herman, Koh Herman menegur dan menceramahi Satri karena Satri berusaha meminta pinjaman kepada Koh Herman, padahal pinjaman sebelumnya belum dilunasi. Seruan yang diberikan Koh Herman di depan para pegawainya tidak hanya didasari kemarahan Koh 
Herman tentang pinjaman yang belum dilunasi Satri, tetapi juga ketidaksukaan Koh Herman atas kebiasaan Satri yang sering datang terlambat dalam bekerja.

s. Fungsi Mengingatkan

Tuturan (19)

Bagus : Pol, jangan lupa doa ya?

Jempol : Iya Pak.

Tuturan (19) dituturkan oleh Bagus dan Jempol. Indikator tuturan Bagus ditandai pada isi tuturan yang berupa nasihat dalam bentuk pengingat. Dalam tuturannya, Bagus mengingatkan kepada Jempol untuk senantiasa membiasakan diri berdoa terlebih dahulu sebelum makan. Indikataor kedua, tuturan Bagus menimbulkan efek kepada Jempol. Efek yang dimaksud adalah Jempol bersedia melakukan sesuatu seperti yang diinginkan oleh Bagus. Hal tersebut terlihat dari tuturan Jempol yang tertulis, Iya Pak.

t. Fungsi Menegur

Tuturan (20)

Jempol : Kita jadi ke Monas, Ancol atau Ragunan Pak?

Satri : : Pol, bapak kamu lagi sakit malah kamu ngajakjalan-jalan.

Tuturan (20) dituturkan oleh Jempol dan Satri. Tuturan Satri yang tertulis, Pol, bapak kamu lagi sakit malah kamu ngajak jalan-jalan, termasuk ke dalam tindak tutur direktif kritikan dengan fungsi menegur. Dalam tuturannya, Satri bermaksud menegur Jempol untuk tidak menanyakan tentang liburan kepada ayahnya yang sedang sakit. Teguran yang diberikan Satri bertujuan agar tidak membenani pikiran ayah Jempol. Selain itu, Satri juga memberikan pelajaran kepada Jempol untuk lebih cerdas dalam menghadapi keadaan sekitarnya, terlebih ayah Jempol yang sedang sakit.

u. Fungsi Menyindir

Tuturan (21)

Tiwi : Dulu kan kamu yang bilang, Tiwi, kalau mau lingkungan kita bersih, kita gak boleh buang sampah sembarangan.

Jempol : Emang aku ngomongnya kayak gitu?

Tuturan (21) dituturkan oleh Tiwi dan Jempol. Indikator tuturan Tiwi ditandai dengan adanya unsur sindiran. Dalam tuturannya, Tiwi menyindir Jempol karena Jempol lupa akan nasihat yang pernah diberikan kepada Tiwi. Adapun sindiran tersebut didasari oleh kekesalan Tiwi terhadap Jempol yang menganggap piagam juara kelas yang diperoleh Jempol dianggap sebagai sampah. Terlebih piagam tersebut dibuang Jempol di tong sampah. Oleh sebab itu, Tiwi mencoba mengingatkan kembali perkataan Jempol di masa lalu melalui sindiran dengan harapan Jempol mengingat perkataannya sendiri dan juga sadar jika piagam yang diperoleh Jempol tersebut bukanlah sampah, melainkan suatu penghargaan yang mempunyai nilai. 
v. Fungsi Mengumpat

Tuturan (22)

Satri : Mas coba dengerin saya, dari kecil saya sudah lahir susah mas.Tapisaya jadi makin susah sama sikap sok suci kamu.

Bagus : Jaga mulutmu Tri!

Tuturan (22) dituturkan oleh Satri dan Bagus. Indikator yang menunjukkan adanya umpatan pada tuturan Satri ditandai dengan pemakaian kata sikap sok suci kamu. Kata sikap sok suci kamu, mempunyai konotasi negatif dan biasanya digunakan oleh seseorang yang tidak terima diperlakukan atau merasa kecewa. Jika melihat dari konteks percakapan keduanya, tuturan Satri dilatarbelakangi oleh ketidakpuasan terhadap pendapat Bagus yang mengatakan bahwa Satri telah berbuat tidak terpuji (mencuri). Tidak hanya itu, Satri mengatakan demikian juga karena tidak merasa puas atas pencapaian hidup selama mereka nikah.

w. Fungsi Marah

Tuturan (23)

Koh Herman : Kenapa sih lu nyolong sama gua? Kurang baik apa gua ke lu?

Satri : Saya nyesel koh, saya nyesel.

Tuturan (23) dituturkan oleh Koh Herman dan Satri. Indikator tuturan Koh Herman dengan adanya pernyataan ketidaksenangan atas sikap Satri. Hal tersebut dapat diketahui dari pemakaian kata Kurang baik apa gua ke lu? Darituturan tersebut, dapat dipahami jika kata tersebut merupakan representasi kemarahan Koh Herman atas sikap Satri yang mencuri uang di apotiknya. Dalam konteks percakapan keduanya, Koh Herman merasa dirinya sudah terlampau baik kepada Satri, akan tetapi dirinya dikhianati oleh sikap Satri yang berani mencuri di apotiknya.

x. Fungsi Melarang

Tuturan (24)

Satri : Mas, buat beli obat, kita pakai uang Jempol, ya?

Bagus : Gakusah, gakusah.

Tuturan (24) dituturkan oleh Bagus dan Satri. Indikator tuturan Bagus ditandai dengan adanya penggunaan kata gak usah. Kata gak usah biasanya digunakan untuk melarang seseorang berbuat sesuatu. Bahkan dalam tuturannya, Bagus menggunakan kata gak usah sebanyak dua kali untuk memperkuat larangan yang ingin dia tujukan kepada Satri. Adapun maksud tuturan Bagus di atas, Bagus melarang Satri menggunakan uang Jempol digunakan untuk membeli obat demi kesembuhan Bagus. 


\section{Implementasi Tindak Tutur Direktif yang Terdapat dalam Film Aku Ingin Ibu Pulang Karya Monty Tiwa sebagai Alternatif Bahan Ajar Teks Drama Kelas XI SMA}

Teks drama sebagaimana tercantum pada silabus mata pelajaran Bahasa Indonesia kelas XI SMA kurikulum 2013 revisi 2018 tidak terlepas dari adanya penggunaan bahasa untuk komunikasi antartokoh yang dikarang oleh pengarang. Hal tersebut juga berlaku pada komunikasi antartokoh yang terdapat dalam film Aku Ingin Ibu Pulang karya Monty Tiwa. Keduanya mempunyai hubungan yang saling terkait, yaitu sama-sama menggunakan bahasa untuk berinteraksi dan berkomunikasi dalam rangka menyampaikan pesan, ide, maupun gagasan. Sejalan dengan itu, hasil penelitian tindak tutur direktif dalam film Aku Ingin Ibu Pulang karya Monty Tiwa digunakan sebagai alternatif bahan ajar teks drama kelas XI SMA, terutama aspek keterampilan yang tercantum pada KD. 4.19, yaitu mendemonstrasikan sebuah naskah drama dengan memperhatikan isi dan kebahasaan. Dengan adanya penelitian tindak tutur direktif dalam film Aku Ingin Ibu Pulang karya Monty Tiwa sesuai dengan pembelajaran teks drama kelas XI SMA, diharapkan memudahkan siswa untuk mencapai pengetahuan tentang teks drama dan mampu mengaplikasikan pengetahuan yang diperolehnya dalam bentuk keterampilan menyusun teks drama.

\section{PENUTUP}

Berdasarkan penelitian yang dilakukan dapat disimpulkan bahwa penggunaan tindak tutur direktif tidak dapat dilepaskan dalam kehidupan manusia. Tindak tutur direktif tidak hanya digunakan sebagai cara komunikasi manusia, akan tetapi juga digunakan untuk menyampaikan pesan secara visual, terutama dalam pembuatan film Aku Ingin Ibu Pulang karya Monty Tiwa. Pada penelitian ini juga menunjukkan bahwa tindak tutur direktif dapat diintegrasikan ke dalam pembelajaran teks drama kelas XI SMA. Dari penelitian ini, penulis menyarankan kepada guru Bahasa Indonesia kelas XI SMA agar menggunakan hasil penelitian ini sebagai alternatif bahan belajar untuk meningkatkan pembelajaran teks drama kelas XI SMA. 


\section{DAFTAR PUSTAKA}

Arikunto, Suharsimi. 2010. Prosedur Penelitian Suatu Pendekatan Praktik. Jakarta: Rineka Cipta.

Chaer, Abdul. 2010. Kesantunan Berbahasa. Jakarta: Rineka Cipta.

Mahsun. 2005. Metode Penelitian Bahasa: Tahapan Strategi, Metode, dan Tekniknya. Jakarta: PT Raja Grafindo Persada.

Moleong, Lexy J. 2010. Metode Penelitian Kualitatif. Bandung: PT Remaja Rosdakarya.

Prayitno, Harun Joko. 2011. Kesantunan Sosiopragmatik. Surakarta: Universitas Muhammadiah Press.

Sudaryanto. 1988. Metode Linguistik (Bagian Pertama: Ke Arah Memahami Metode Linguistik). Yogyakarta: Gadjah Mada University Press.

Sugiyono. 2014. Metode Penelitian Kuantitatif, Kualitatif dan R\&D. Bandung: Alfabeta.

Yule, George. 2014. Pragmatik. Yogyakarta: Pustaka Pelajar. 